\title{
Tomato Flower Abnormalities Induced by Stolbur Phytoplasma Infection Are Associated with Changes of Expression of Floral Development Genes
}

\author{
Pascale Pracros, ${ }^{1}$ Joël Renaudin, ${ }^{1}$ Sandrine Eveillard, ${ }^{1}$ Armand Mouras, ${ }^{2}$ and Michel Hernould ${ }^{2}$ \\ ${ }^{1}$ UMR 1090 Génomique Développement et Pouvoir Pathogène, INRA-Université de Bordeaux 2, Centre INRA de Bordeaux, \\ 71 avenue Edouard Bourlaux, B.P. 81, 33883 Villenave d'Ornon Cedex, France; ${ }^{2}$ UMR 619 Physiologie et Biotechnologie \\ Végétales, INRA-Université de Bordeaux 1-Université de Bordeaux 2, Centre INRA de Bordeaux, 71 avenue Edouard \\ Bourlaux, B.P. 81, 33883 Villenave d'Ornon Cedex, France
}

Submitted 13 July 2005. Accepted 16 September 2005.

Tomato (Lycopersicon esculentum cv. Micro-Tom) plants infected by the stolbur phytoplasma (isolate PO) display floral abnormalities, including sepal hypertrophy, virescence, phyllody, and aborted reproductive organs, which are reminiscent of those observed in Arabidopsis thaliana mutants affected in flower development genes. Semiquantitative reverse transcription-polymerase chain reaction and in situ RNA hybridization were used to compare expressions of meristem and flower development genes in healthy and stolbur phytoplasma-infected tomatoes. In infected plants, FALSIFLORA (FA), controlling the identity of the inflorescence meristem, was up-regulated, whereas $L$ WUSCHEL (LeWUS) and LeCLAVATAI (LeCLVI), regulating the meristem development, and LeDEFICIENS (LeDEF), responsible for the organ (petals and stamens) identity within the flower, were down-regulated regardless of the development stage of the flower bud. In contrast, expression of TAG1, which regulates stamen and carpel identities and negatively controls $L e W U S$, was up-regulated at the early stages and down-regulated at the late stages. In situ RNA hybridization analyses revealed that TAG1 transcripts were restricted to the same floral meristem territories in healthy and infected tomatoes, indicating that tissue-specific expression of TAG1 was not affected by the stolbur phytoplasma infection. Taken together, these data indicate that flower malformations of stolbur phytoplasma-infected tomatoes are associated with early changes in the expression of key flower development genes. The possible mechanisms by which the multiplication of stolbur phytoplasma in tomato sieve tubes deregulates floral development are discussed.

Phytoplasmas are plant pathogenic bacteria belonging to the class Mollicutes, a group of wall-less organisms phylogenetically related to low $\mathrm{G}+\mathrm{C}$ content, gram-positive bacteria (Weisburg et al. 1989). Phytoplasmas are associated with several hundred diseases affecting a large variety of plants, including grapevine, fruit trees, ornamentals, and vegetables (Lee et al. 2000; Seemüller et al. 2002), in which they induce severe symptoms resulting in crop losses. In the host plant, phytoplasmas are restricted to the phloem sieve tubes, in which they move down to the roots and up to the top of the plants but never settle in the meristems (Christensen et al. 2004; Kuske

Corresponding author: J. Renaudin; E-mail: renaudin@bordeaux.inra.fr; Telephone: +(33) 5.57.12.23.61; Fax: +(33) 5.57.12.23.69. and Kirkpatrick 1992). Phytoplasmas have very rarely been detected in floral tissue (Cordova et al. 2003). In the wild, phytoplasmas are transmitted between plants by phloem sap-sucking insects of the Psyllidae, Cicadellidae, and Cixidae families, in which they multiply (Lee and Davis 1992). The detection and classification of phytoplasmas have benefited from the classical molecular biology methods (Lee et al. 1998; Seemüller et al. 1998). However phytoplasmas have not been cultured so far. Phytoplasma infection is thought to affect phloem function, impairing translocation of carbohydrates with subsequent effects on photosynthesis (Lepka et al. 1999; Maust et al. 2003). However mechanisms by which the bacteria cause diseases in plants are poorly understood.

Phytoplasmas can cause a wide variety of symptoms, including yellowing, stunting, proliferations, and flower malformations, some of which (witches' broom, virescence) are specific to certain phytoplasma groups or isolates (Lee et al. 2000). Stolbur phytoplasma infection has been shown to strongly and specifically affect floral morphology. For years it has been known that the stolbur disease causes damage in various plants including tomato, in which it induces flower malformations (Messiaen and Marrou 1967; Valenta et al. 1961), and it is known that, in a given host plant, symptoms may differ depending on the stolbur isolate (Marchoux and Messiaen 1967; Marchoux et al. 1969). When it was first reported on tobacco (Kostoff 1933), stolbur disease was named "female sterility" because infected plants showed flower malformations, such as virescence and phyllody, and failed to produce seeds. The same disease reported on tomato in Australia was named "big bud," due to hypertrophy of the flower buds (Hill 1943). In stolbur-diseased plants, the most obvious examples of flower abnormalities are the development of green flowers and the loss of normal flower pigment (virescence), the development of floral organs into leafy structures (phyllody), and in some cases, malformations of the stamens and carpels leading to plant sterility (Cousin and Abadie 1982). Similar symptoms have been observed in periwinkle (Catharanthus roseus) plants infected by the isolate PO of stolbur phytoplasma (Jarausch et al. 2001), but the molecular mechanisms by which phytoplasma multiplication in the sieve tubes interferes with the plant physiology and especially with flower development have not been described.

The past decade has seen great advances in understanding of molecular and genetic mechanisms that underlie floral induction, floral patterning, and floral organ identity. The most detailed and comprehensive picture of the molecular mechanisms 
underlying flower development came from studies performed in Arabidopsis thaliana. This accumulated knowledge of the floral patterning mechanisms applies to a wide range of plant species. From these studies, unifying principles of flower development have been proposed. The first, called the ABC model (Weigel and Meyerowitz 1994; Yanofsky 1995), postulates that three activities, A (APETALA1 and APETALA2 genes), $\mathrm{B}$ (APETALA3 and PISTILATA genes), and C (AGAMOUS gene), specify floral organ identity in a combinatorial manner. A alone specifies sepals, A and B specify petals, B and C specify stamens, and $\mathrm{C}$ alone specifies carpels. The second unifying principle involves the central role of the $L E A F Y(L F Y)$ gene in defining a meristem as floral (Weigel and Nilsson 1995), in integrating the outputs of floral inductive pathways (Blazquez and Weigel 2000), and in activating the floral organ identity genes (Lenhard et al. 2001; Lohmann et al. 2001; Parcy et al. 1998; Weigel and Meyerowitz 1993).

Generally, flower development can be divided into four stages that occur in a temporal sequence: i) switch from vegetative to reproductive growth in response to both environmental and endogenous signals, ii) activation of a small group of meristem identity genes (including $L F Y$ ) that specify floral identity, iii) activation of floral organ identity genes (ABC model) by the meristem identity genes, including $L F Y$, and iv) floral organ identity genes activating downstream "architect" genes that specify the tissues of the four floral whorls.

Interestingly, flower abnormalities specifically induced in stolbur phytoplasma-infected tomato plants resemble those described in A. thaliana floral organ mutants such as agamous (ag) and apetala 3 (ap3), identity meristem mutants such as leafy (lfy), and shoot apical meristem mutants such as wuschel (wus) and clavata (clv) (Bowman et al. 1991; Coen and Meyerowitz 1991; Reeves and Coupland 2001). Orthologs of the corresponding genes are present in a wide range of flowering plant species (Frohlich and Parker 2000; Gocal et al. 2001). Therefore, based on the flower development regulation model of $A$. thaliana, we chose to study the expression pattern of FALSIFLORA (FA), LeWUSCHEL (LeWUS), LeCLAVATAI (LeCLV1), TAG1, and LeDEFICIENS (LeDEF), orthologs of $A$. thaliana genes $L F Y, W U S, C L V 1, A G$, and $A P 3$, respectively. In this study, we have compared expression of the genes in developing flower buds of healthy and stolbur phytoplasmainfected tomatoes by semiquantitative reverse transcriptionpolymerase chain reaction (RT-PCR) and in situ hybridization. In agreement with the morphological and anatomical changes, expression of key floral development genes was found to be impaired by stolbur phytoplasma infection. The nature of the signal inducing the modifications of gene expression associated with the phytoplasma infection is discussed.

\section{RESULTS}

\section{Flower abnormalities}

of stolbur phytoplasma-infected tomato plants.

Infection of periwinkle plants by the stolbur phytoplasma causes disorders of floral development, resulting in abnormal flower phenotypes (Jarausch et al. 2001). In this study, we describe the flower abnormalities of tomato plants (L. esculentum, cv. Micro-Tom) infected by the isolate PO of the stolbur phytoplasma. A morphological comparison of flowers from healthy and stolbur phytoplasma-infected tomato plants revealed drastic malformations of floral organs (Fig. 1). Inflorescences of infected plants showed an upright bearing with thicker petioles (Fig. 1C) than in healthy plants (Fig. 1A) and flowers displayed enlarged calyces with aborted whorls known as the big bud symptom (Fig. $1 \mathrm{G}$ and $\mathrm{H}$ ). Additional flower abnormalities were sepal hypertrophy (Fig. 1D, E, and F), small-size green- colored petals (virescence) (Fig. 1D), and leafy sepals (phyllody) (Fig. 1E and F). While flowers from healthy tomatoes possessed five fused yellow stamens covering the two carpels (Fig. 1A and B), those from phytoplasma-infected plants had green-colored stamens (Fig. 1D) or no stamens and no carpels (Fig. 1E and G), leading to plant sterility.

To determine how and at which stage the modifications of flower organs occurred in infected plants, histological analyses of flower buds from healthy and stolbur phytoplasma-infected plants were performed at several timepoints during flower development. Symptoms of organ malformation were clearly detected in flower buds of 1.5 to $2 \mathrm{~mm}$ in length, i.e., stage 7 to 8 of the tomato flower development schedule (Brukhin et al. 2003). Flower buds of infected plants were usually enlarged as compared with healthy ones (Fig. 2) and displayed floral organ abnormalities. In healthy plants at stage 7 to 8 , the sepal whorl fully enclosed the three inner whorls to form the floral bud (Fig. 2A), while in diseased plants sepals were hypertrophied
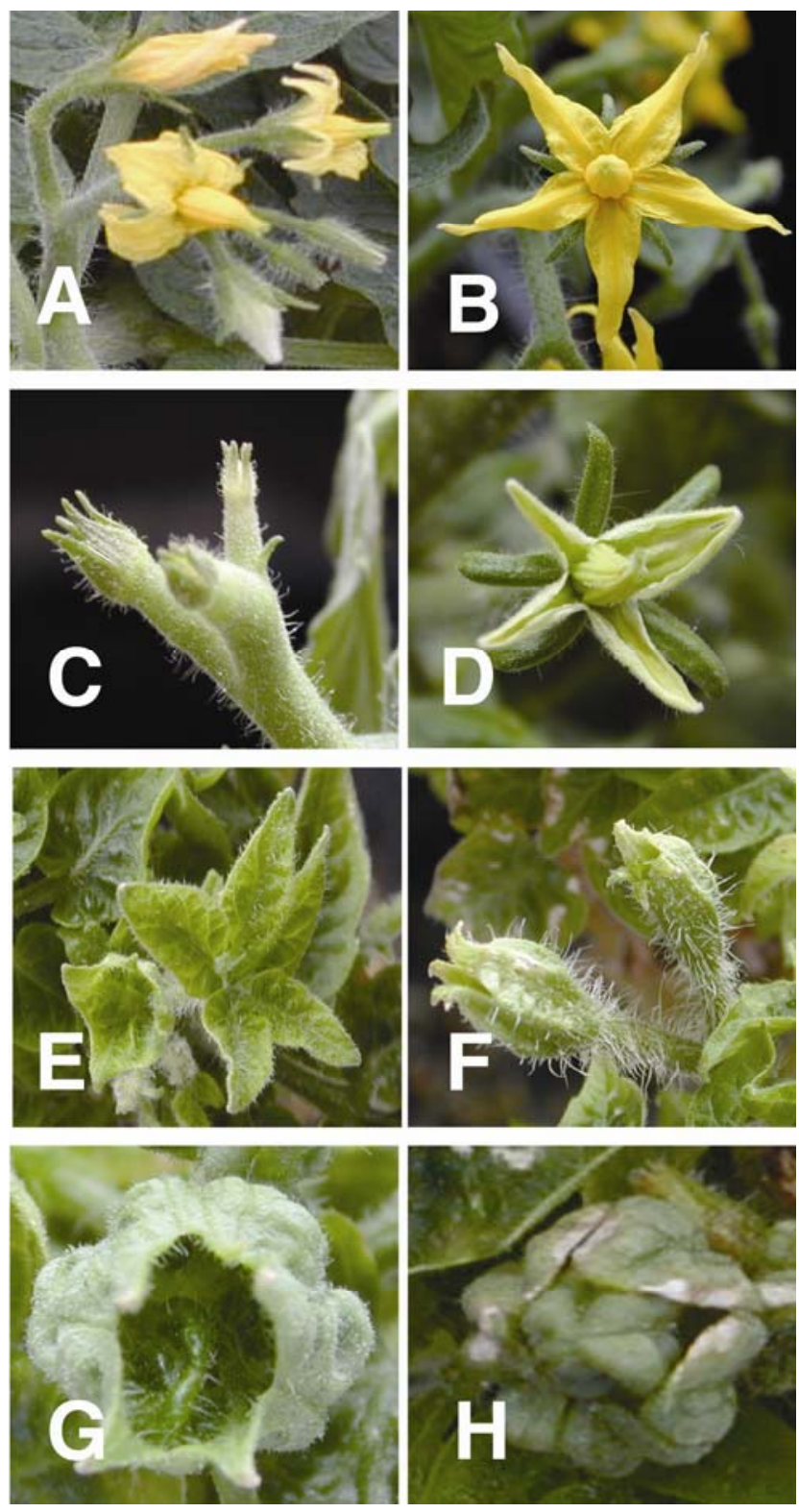

Fig. 1. Mature flowers of $\mathbf{A}$ and $\mathbf{B}$, healthy and $\mathbf{C}, \mathbf{D}, \mathbf{E}, \mathbf{F}, \mathbf{G}$, and $\mathbf{H}$, stolbur phytoplasma-infected tomato plants. Notice sepal hypertrophy (D), green petals and stamens (D), leafy structure of sepals ( $E$ and $F$ ), absence of petals (E, F, G, and H), stamens, and carpels (E and G), and overdeveloped petioles (C). 
and failed to close the flower bud (Fig. 2B). Similarly, growing petals of healthy plants covered the stamens where archesporial cells (leading to pollen grains) differentiated, while in infected plants, stamens stopped developing prematurely, explaining the male sterility of these plants. In healthy plants, whorl 4 showed typical carpel fusion and placental column formation (Fig. 2A). In contrast, in diseased plants, carpel primordia did not fuse properly, leading to the formation of an abnormal pistil (Fig. 2B) and accounting for female sterility.

\section{Expression of floral development genes is deregulated in diseased plants.}

Considering the flower development regulation pathway and the phenotype of diseased tomato plants, it was hypothesized that expression of genes controlling floral meristem and flower organ identities, as well as the architect organ genes, was impaired. In particular, the occurrence of flowers having a leaflike structure in whorls 1 and 2 and lacking one or both of whorls 3 and 4 suggested that expression of genes controlling the maintenance of the shoot apical meristem and the floral organ identity was deregulated. Taken together, these morphological and anatomical flower abnormalities were, to some extent, reminiscent of those of A. thaliana mutants such as ap3, ag, lfy, wus, and clv1 (Bowman et al. 1991; Coen and Meyerowitz 1991; Reeves and Coupland 2001), suggesting that gene orthologs of $W U S, C L V 1, L F Y, A P 3$, and $A G$ could be deregulated in tomato plants infected with the stolbur phytoplasma.

Therefore, we compared the expression patterns of genes LeWUS, LeCLVI, FA, LeDEF, and TAG1, respectively, orthologs of A. thaliana genes WUS, CLV1, LFY, AP3, and $A G$, in healthy and stolbur phytoplasma-infected tomato plants. Semi-

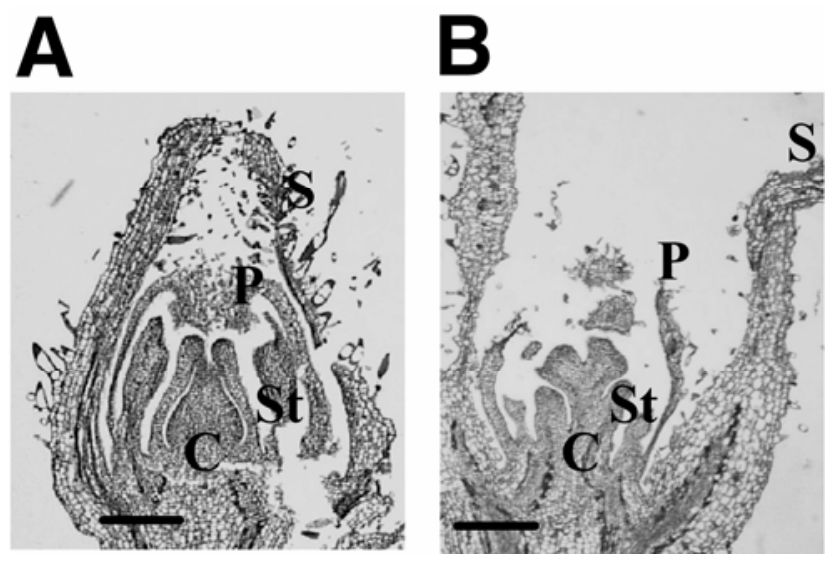

Fig. 2. Longitudinal sections of tomato floral buds from $\mathbf{A}$, healthy and $\mathbf{B}$, stolbur phytoplasma-infected tomato plants. Floral organ modifications were sepal $(\mathrm{S})$ hypertrophy, petals $(\mathrm{P})$ with reduced sizes, aborted stamens $(\mathrm{St})$, and carpels $(\mathrm{C})$. Bars $=0.3 \mathrm{~mm}$. quantitative RT-PCR was used to determine gene expression levels during flower development. Specific primers were designed for LeWUS, LeCLVI, FA, LeDEF, and TAG1 (Table 1). LeACTIN, which has been shown to be constitutively expressed in tomato (Germain et al. 1997), was used as the gene expression control.

In the first set of experiments, total RNAs were extracted from flower buds at stage 9, and RT-PCR was carried out with two independent RNA preparations. The results presented in Figure 3A clearly show that, in stolbur phytoplasma-infected plants, LeWUS, LeCLVI, and LeDEF were down-regulated with reduction of, respectively, 42,26 , and $56 \%$ of the transcript level, whereas $F A$ was up-regulated (24\%). Unexpectedly, TAG1 was equally expressed both in healthy and diseased plants.

To further establish the relationships between flower malformations and misregulation of genes involved in meristem functioning and floral organ development, spatial and tissue-specific expression patterns of LeWUS, LeCLVI, and TAG1 were studied by in situ RNA hybridization. Longitudinal sections of vegetative and floral meristems (at stage 4) from healthy and stolbur phytoplasma-infected tomato plants were hybridized with digoxigenin-labeled antisense and sense (negative control) probes. Transcription product of LeWUS, which is specifically expressed in the apical meristem, was faintly detected in vegetative meristem of healthy plants. The transcripts were detected in the central zone of the meristem and the area including corpus and L2 and L3 cell layers (Fig. 3B) (Bowman and Eshed [2000] provide a description of meristem structure). In diseased plants, LeWUS transcripts were almost undetectable. The LeCLV1 transcripts were detected in the whole meristem of healthy plants but were detected only poorly or not at all in infected plants (Fig. 3B). These data clearly indicated that LeWUS and LeCLVI were down-regulated in the apical meristem. However, no spatial changes in the expression of these genes were observed. Transcripts of the floral organ identity gene TAGl were clearly detected throughout the floral meristem both in healthy and diseased plants (Fig. 3B). These data confirmed those obtained by RT-PCR, showing a similar level of expression of TAG1 in healthy and stolbur-diseased plants. As expected, hybridizations with sense probes did not show any signal above the background level (data not shown).

To gain further information about the expression timecourse of these genes, the transcript levels of LeWUS, LeCLV1, FA, and TAGl were determined by RT-PCR at various stages of flower-bud development (Fig. 4). Two independent RNA preparations from healthy and infected tomato were extracted from floral buds at stages $6,9,12$, and 15 . The results are reported in Figure 4. The LeWUS and LeCLVI transcript levels in healthy and diseased plants paralleled all along the flower development. In diseased plants, however, the transcript levels were, respectively, 40 and $25 \%$ lower than in healthy ones, in agreement with data obtained at stage 9 (Fig. 3A). In the case

Table 1. Primers used in this study

\begin{tabular}{|c|c|c|c|c|}
\hline Primer & Nucleotide sequence $\left(5^{\prime}-3^{\prime}\right)$ & Position & Accession number & Target gene \\
\hline LEACTF5 & TGGCATCATACTTTCTACAATG & 323 to 345 & U60480 & LeACTIN \\
\hline LEACTR3 & CTAATATCCACGTCACATTTCAT & 1,118 to 1,140 & U60480 & LeACTIN \\
\hline LEAP3F5 & GGTTGAGTAGTAATTTTCACC & 922 to 942 & TC116723 & $L e D E F$ \\
\hline LEAP3R3 & TTCATACTTCCACATGATC & 1,177 to 1,195 & TC116723 & $L e D E F$ \\
\hline LEWUSF5 & CTGCCGCCTCTGCCACTG & 313 to 330 & AJ538329 & LeWUS \\
\hline LEWUSR3 & CAAGAAAAGGGTAAGTTGCTGG & 612 to 633 & AJ538329 & LeWUS \\
\hline LEAGF5 & AATGGAGCAGGTATTCTG & 848 to 865 & AY098735 & TAG1 \\
\hline LEAGR3 & GGCTGTAAAAGTATATAGAAG & 1,046 to 1,066 & AY098735 & TAG1 \\
\hline LEFAF5 & CGCGGACACATTTTGTCC & 518 to 535 & AF197936 & $F A$ \\
\hline LEFAR3 & CTTTGTCTCTCGCTTATTCC & 1,100 to 1,119 & AF197936 & $F A$ \\
\hline LECLV1F5 & CTATGTCAAATGGCATCGAC & 34 to 53 & AW979740 & LeCLV1 \\
\hline LECLV1R3 & CACAGCAATACGGTACCTTG & 274 to 293 & AW979740 & LeCLV1 \\
\hline
\end{tabular}


of $F A$, the transcript level was constantly higher (approximately 25\%) in diseased plants regardless of the flower-development stage. Unexpectedly, while the TAG1 transcript level increased from stage 6 to stage 15 of flower development in healthy plants, it did not significantly increase over time in diseased ones. At stage 6, the TAG1 transcript level of stolburinfected plants was higher than in healthy ones.

\section{DISCUSSION}

Infection of tomato plants by the stolbur phytoplasma isolate PO induces severe symptoms such as leaf yellowing and deformations, reduced root volume, and typical flower malformations including uprighted inflorescences, virescence, phyllody, and big buds. The traits exhibited by diseased plants suggest that the genetic regulation pathway of flower development is impaired. To understand the molecular mechanisms that are responsible for the abnormal development of flowers in stolbur phytoplasma-infected tomatoes, we have studied the expression patterns of essential genes of floral development in the light of the A. thaliana model (Blazquez 2000). In agreement with the fact that flowers from infected plants possessed degenerated or no petals, $L e D E F$, an ortholog of $A P 3$, which is required for petal formation (Krizek and Meyerowitz 1996; Lohmann and Weigel 2002), was down-regulated. Because flowers from stolbur phytoplasma-infected plants lack stamens and carpels, expression of TAG1 (ortholog of AG) was expected to be down-regulated. Indeed, kinetic studies revealed that, in contrast to the situation in healthy plants, in which TAG1 RNA was found to accumulate from stage 6 to stage 15 , no such accumulation was observed during flower development of infected plants. In these plants, the expression of TAG1, which seemed to be activated earlier than in healthy plants, did not significantly vary from stage 6 to stage 15. The misregulation of TAG1 in diseased plants may account for the alteration or the absence of flower reproductive organs. The termination of stem cell maintenance correlates with the transformation from the indeterminate to determinate state in A. thaliana floral meristems. This transformation is triggered by the interaction between $W U S$ and $A G$ through a temporal autoregulatory mechanism (Lenhard et al. 2001). The model suggests that WUS specifies shoot apical cells as stem cells in young flower primordia and thus provides the full complement of cells to the forming organs. In addition, in the center of the floral meristem, WUS activates the expression of $A G$, which, in turn, represses $W U S$, resulting in termination of stem cell maintenance. In diseased tomato plants, TAG1 seems to be prematurely activated, as suggested by the fact that, at the early stages, expression level was significantly higher in diseased plants than in healthy ones. This early activation could result in a premature down-regulation of LeWUS and, consequently, in a premature arrest of stem cell production. Therefore, the possibility that the autoregulatory mechanisms governing spatial and temporal aspects of stem cell regulation in $A$. thaliana also take place in tomato cannot be excluded.

In the A. thaliana model (Lenhard et al. 2001), the activation of $A G$ by $W U S$ requires $L F Y$ to specify floral meristems. In healthy tomato plants, the expression patterns of these three genes seem to evolve in agreement with this model. In contrast, in diseased tomato plants, TAGl was not up-regulated in spite of overexpression of $F A$. In this case, it is thought that downregulation of LeWUS would be responsible for the lower transcript level of TAG1. These data are in good agreement with those obtained in A. thaliana (Doerner 2001), in which the two transcriptional regulators ( $L F Y$ and $W U S)$ synergistically interact to activate $A G$. In addition, the expression of

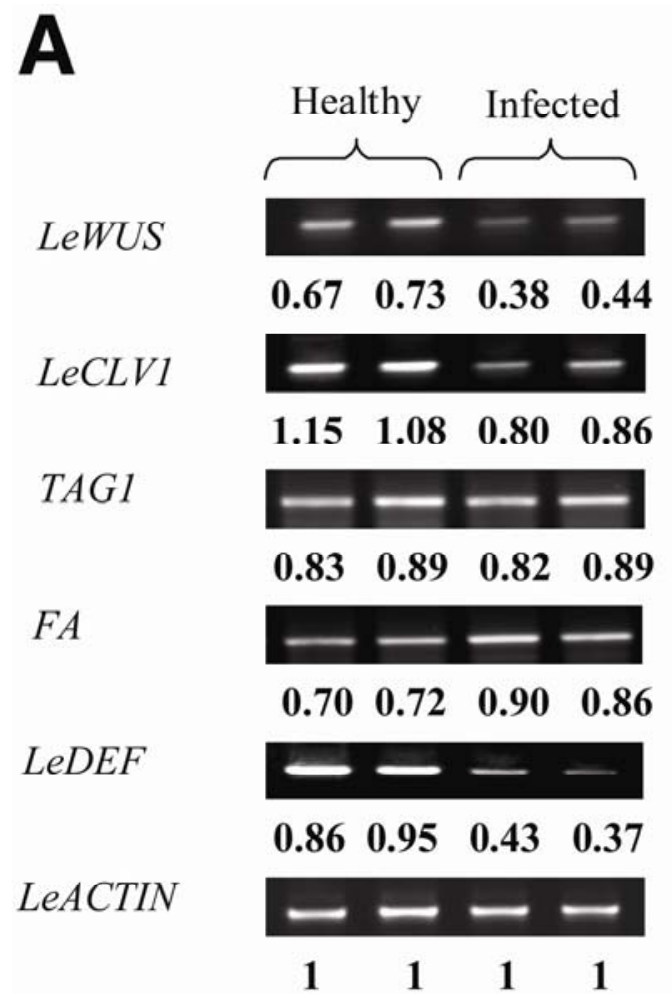

B

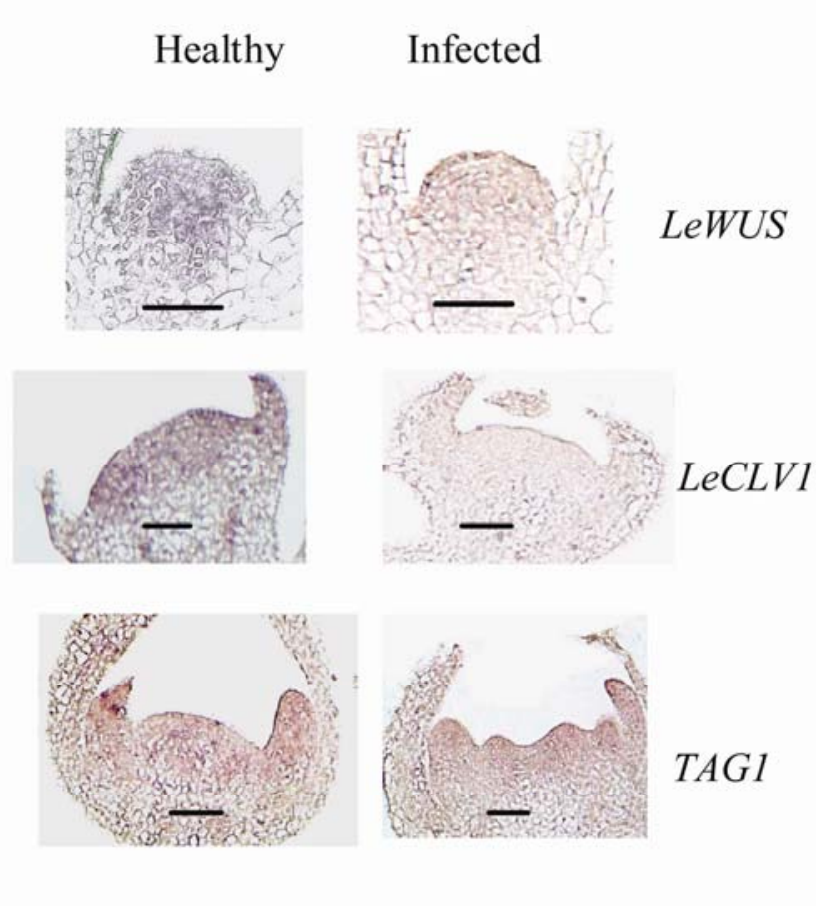

Fig. 3. A, Evaluation of LeWUS, LeCLV1, FA, TAG1, LeDEF, and LeACTIN transcript levels by semiquantitative reverse transcription-polymerase chain reaction. Data were obtained with two independent RNA preparations from healthy and stolbur phytoplasma-infected flower buds (at stage 9). Values were obtained using Quantity One software and were normalized using LeACTIN as the reference. B, In situ RNA hybridization patterns of LeWUS, LeCLVI, and TAG1 transcripts in longitudinal sections of floral meristems (at stage 4) from healthy and stolbur phytoplasma-infected tomato. Whereas all three gene transcripts were detected in healthy meristems, only $T A G 1$ transcript was detected in meristems of stolbur phytoplasma-infected plants. Bars $=0.1 \mathrm{~mm}$. 
LeCLV1, which is involved in promoting organ initiation and in negatively regulating $L e W U S$, was significantly down-regulated in stolbur-diseased plants. This may account for petiole and flower hypertrophy, as it was observed in A. thaliana $\mathrm{clv}$ mutants (Lita et al. 2003).

The model describing the signaling pathways that promote flowering and floral architecture in A. thaliana was based on the characterization of mutants affected in flowering time, floral meristem identity, and floral organ identity (Blasquez 2000). Interestingly, the biotic stress induced by stolbur phytoplasma led to a similar development model, in which LeCLV1 and LeWUS are down-regulated (Fig. 5). Because phytoplasma cells have never been detected in the apical meristem, the signal inducing the misregulation of the flower development genes is most likely a long-distance signal. Sugar signaling may be important in floral transition, and the amount of circulating sucrose may be an indicator of the metabolic state of the plant as indicated previously (Blazquez et al. 1998; Wu et al. 2005). Furthermore, the effects of sugars on the expression of genes such as $L F Y$ are important in controlling floral transition (Blazquez 2000; Ohto et al. 2001). Interestingly, phytoplasma infection has been shown to affect phloem function, impairing translocation of carbohydrates with subsequent accumulation of soluble sugars in source leaves (Lepka et al. 1999; Maust et al. 2003). Accumulation of glucose was also observed in periwinkle infected by the cultivable plant mollicute Spiroplasma citri (André et al.
2005). In S. citri-infected periwinkle plants, however, no characteristic flower malformations were observed.

In plants and animals, the cytosine methylation process is known to regulate gene expression in an epigenetic manner. Recent studies have demonstrated that genes can be accidentally down-regulated when the number of methylated cytosines is more abundant as compared with the normal methylation

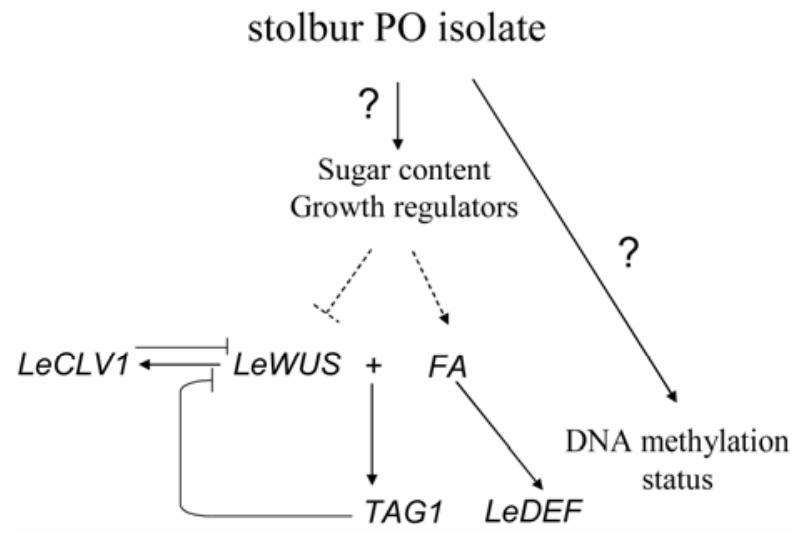

Fig. 5. Hypothetical model showing the putative relationship between the physiological modifications induced by the stolbur phytoplasma infection and the deregulations of meristem maintenance and flower development genes in tomato.

\section{A}

Flower development stages

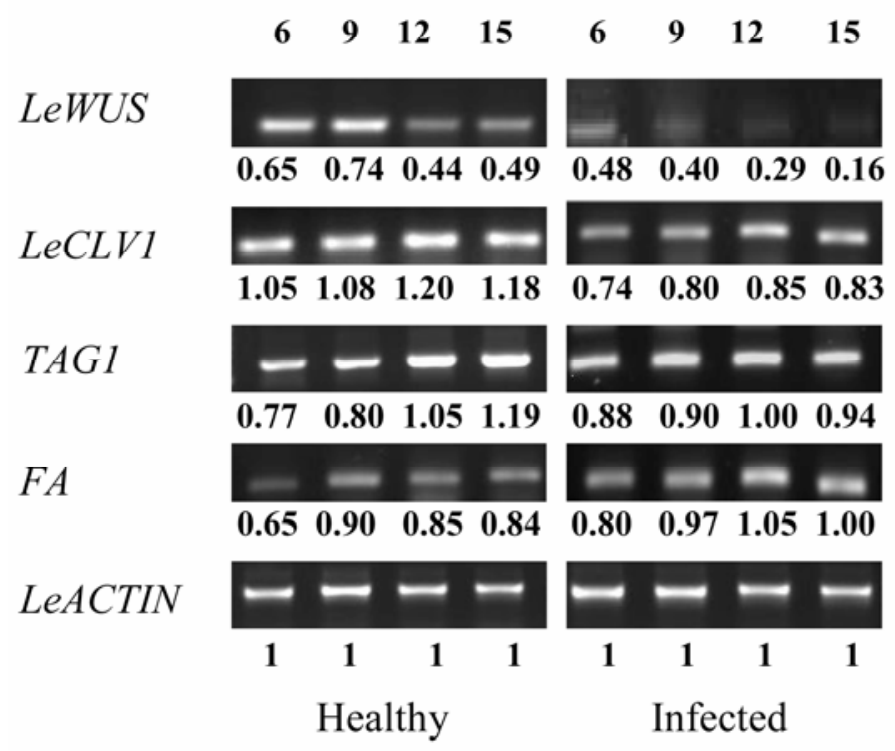

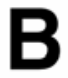

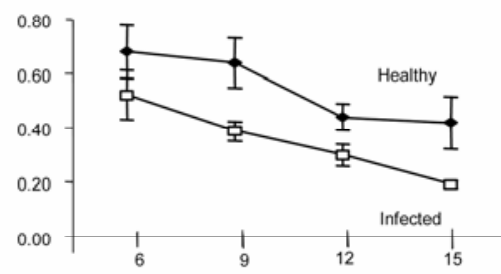

LeWUS

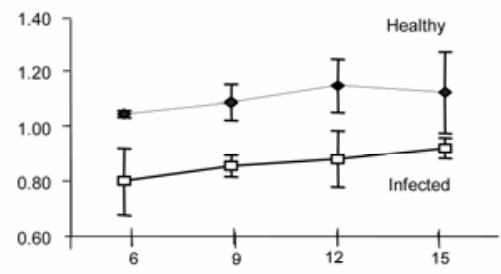

LeCLV1

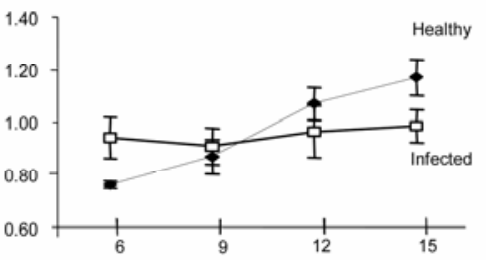

$T A G 1$

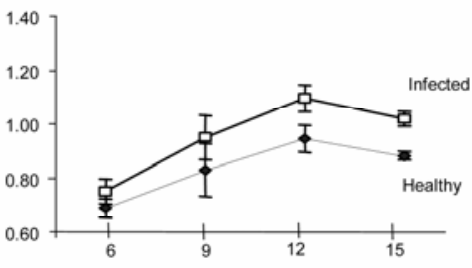

$F A$

Flower development stages

Fig. 4. Comparison of transcript levels of LeWUS, LeCLV1, TAG1, and FA in healthy ( $)$ and stolbur phytoplasma-infected ( $\square$ ) tomato floral buds at stages 6, 9, 12, and 15. Each point represents the average of two (stages 6, 12, and 15) or four (stage 9) independent replicates. Standard deviation bars are indicated. 
status of the gene (Jacobsen et al. 2000). This phenomenon is called "hypermethylation." Moreover, regarding the putative link between hypermethylation and floral abnormalities, it has been suggested that plant genome hypermethylation may result from the activity of a plant defense mechanism (Kishimoto et al. 2001). In this respect, it would be of interest to determine whether a correlation can be established between hypermethylation of genomic DNA sequences and floral modifications of stolbur-infected tomatoes.

In summary, we have shown that tomato floral abnormalities induced by stolbur phytoplasma infection are associated with changes in the expression of flower development genes and, to some extent, mimic phenotypes of A. thaliana homeotic mutants in which a floral organ may be absent or modified to another organ type. However the pathways from stress perception, i.e., phytoplasma multiplication in the phloem sieve tubes, to its specific response, i.e., deregulation of floral meristem gene expression, are still to be deciphered.

\section{MATERIALS AND METHODS}

\section{Biological material.}

The stolbur phytoplasma isolate PO (STOL-PO) belongs to the 16S rDNA XII-A phylogenetic group (Pracros et al. 2001). It was initially introduced into periwinkle (Catharanthus roseus) plants through insect (Hyalestes obsoletus) transmission (Jarausch et al. 2001). STOL-PO was maintained in periwinkle plants by successive grafting in an insect-proof greenhouse. Tomato (Lycopersicon esculentum cv. Micro-Tom) plants (Meissner et al. 1997) were grown from seed and maintained in the greenhouse $\left(27^{\circ} \mathrm{C}\right.$ day, $20^{\circ} \mathrm{C}$ night $)$. The stolbur phytoplasma was transferred from periwinkle to tomato plants by the method of Valenta and associates (1961) using dodder (Cuscuta campestris), a phloem sap-feeding parasitic plant, and was further propagated in tomato by side-grafting. For gene expression studies, batches of two-month-old tomato seedlings were side-grafted with pieces of bark from healthy (control plants) or STOL-PO-infected plants. Colonization of plants by the stolbur phytoplasma was followed by PCR using primer pair fU5 and rU3 (Ahrens and Seemüller 1992) and symptom observation.

\section{RNA isolation.}

Total RNAs were isolated by the Tri-Reagent (Sigma-Aldrich, St. Louis) protocol. Briefly, $0.2 \mathrm{~g}$ of frozen, young flower buds was ground in liquid nitrogen and the powder was mixed with $2 \mathrm{ml}$ of Tri-Reagent. After $10 \mathrm{~min}$ at room temperature, the mixture was centrifuged $\left(12,000 \times g\right.$ for $10 \mathrm{~min}$ at $\left.4^{\circ} \mathrm{C}\right)$ and the supernatant $(1 \mathrm{ml})$ was emulsified with $0.3 \mathrm{ml}$ of chloroform. After centrifugation, the nucleic acids were precipitated from the supernatant by adding an equal volume of cold isopropanol and were collected by centrifugation. Nucleic acids were dissolved in $50 \mu \mathrm{l}$ of sterile water. The RNA concentration was determined with a UV spectrophotometer at $\lambda=260 \mathrm{~nm}$.

\section{Semiquantitative RT-PCR analysis.}

Total RNAs from flower buds $(1 \mu \mathrm{g})$ were treated with DNase RQ1 (Promega, Madison, WI, U.S.A.) at $37^{\circ} \mathrm{C}$ for 1 $\mathrm{h}$, and were then reverse-transcribed using $5 \mu \mathrm{M}$ specific primer and $200 \mathrm{U}$ of Superscript II reverse transcriptase (Invitrogen, Carlsbad, CA, U.S.A.) in a $20-\mu l$ reaction mixture containing $10 \mathrm{mM}$ dithiothreitol, $20 \mu \mathrm{M}$ dNTPs, and 40 $\mathrm{U}$ of RNase Out (Invitrogen). The reaction was performed according to the recommended protocol, except that the mixture was heat-denatured at $65^{\circ} \mathrm{C}$ for $5 \mathrm{~min}$ before adding the reverse transcriptase. PCR amplification was carried out from $2 \mu \mathrm{l}$ of the RT reaction mixture in the presence of $2 \mu \mathrm{M}$ each primer and $1.5 \mathrm{U}$ of Taq DNA polymerase (Invitrogen). The annealing temperature and the number of PCR cycles varied depending on the primers used. Primer sequences and their respective target genes are listed in Table 1. The PCR products were separated by $1.5 \%$ agarose gel electrophoresis in $1 \times$ Trisacetate-EDTA buffer and were stained with ethidium bromide. The band intensities were quantified using Bio-Rad Fluor-S Max MultiImager system and Quantity One software (BioRad, Hercules, CA, U.S.A.).

\section{Histological analysis.}

Floral buds were fixed for $4 \mathrm{~h}$ in the fixative solution FAA (formaldehyde, $4 \% \mathrm{wt} / \mathrm{vol}$; ethanol, $50 \% \mathrm{vol} / \mathrm{vol}$; acetic acid, $5 \% \mathrm{vol} / \mathrm{vol}$ ) at room temperature. Every hour the fixative was replaced and vacuum $(-0.9$ bar $)$ was applied for $15 \mathrm{~min}$. Then samples were treated as described by Gabe (1968). Longitudinal sections ( $8 \mu \mathrm{m}$ thick) were stained with $0.1 \%$ (wt/vol) toluidine blue.

\section{In situ RNA-hybridization.}

Floral meristems were fixed in FAA $(50 \%$ vol/vol ethanol, $5 \% \mathrm{vol} / \mathrm{vol}$ glacial acetic acid, $10 \% \mathrm{vol} / \mathrm{vol}$ formaldehyde) under vacuum at room temperature for $4 \mathrm{~h}$. Then, they were dehydrated through a graded ethanol series and were embedded in paraffin (Paraplast plus, Sigma-Aldrich). Embedded tissue was sliced into longitudinal sections ( $8 \mu \mathrm{m}$ thick) with a microtome (Shandon AS325) and was applied to APES (aminopropyltriethoxysilane)-coated glass slides as described previously (Farbos et al. 2001). Fragments of the tomato cDNAs LeWUSCHEL, LeCLAVATA1, and TAG1 orthologs of the A. thaliana genes WUSCHEL, CLAVATA1, and AGAMOUS, respectively, were generated by PCR amplification of tomato leaf cDNAs with specific primers (Table 1) and were inserted into the pGEMT-EASY vector (Promega.). Sense (negative control) and antisense RNA probes labeled with [digoxigenin]dUTP were prepared from linearized plasmids according to the manufacturer's instructions (Roche Diagnostic, Mannheim, Germany). Pretreatment, hybridization, and washing of slides were performed as described previously (Farbos et al. 2001). Floral meristems of healthy and infected tomatoes were processed in the same way and were placed on the same slide. Hybridization of the probe was revealed with antidigoxygenin-alkaline phosphatase conjugate using NBT-BCIP (nitroblue tetrazolium and 5-bromo-4-chloro-3-indolyl phosphate) as the substrate and was detected as purple or blue staining. Images were processed and prepared for presentation with Photoshop 6.0 (Adobe System Inc., Seattle).

\section{ACKNOWLEDGMENTS}

This work was financially supported by INRA-Région Aquitaine (grant number BO5473) and by INRA (grant number 2004-1090-01). We thank P. Bonnet for growing and grafting plants.

\section{LITERATURE CITED}

Ahrens, U., and Seemüller, E. 1992. Detection of DNA of plant pathogenic mycoplasma-like organisms by a polymerase chain reaction that amplifies a sequence of the 16S RNA gene. Phytopathology 82:828-832.

André, A., Maucourt, M., Moing, A., Rolin, D., and Renaudin, J. 2005. Sugar import and phypathogenicity of Spiroplasma citri: Glucose and fructose play distinct roles. Mol. Plant-Microbe Interact.18:33-42.

Blazquez, M. A. 2000. Flower development pathways. J. Cell Sci. 113:3547-3548.

Blazquez, M. A., and Weigel, D. 2000. A thermosensory pathway controlling flowering time in Arabidopsis thaliana. Nat. Genet. 33:168-171.

Blazquez, M. A., Green, R., Nilsson, O., Sussman, M. R., and Weigel, D. 1998. Gibberellins promote flowering of Arabidopsis by activating the $L E A F Y$ promoter. Plant Cell 10:791-800. 
Bowman, J. L., and Eshed, Y. 2000. Formation and maintenance of the shoot apical meristem. Trends Plant Sci. 5:110-115.

Bowman, J. L., Smyth, D. R., and Meyerowitz, E. M. 1991. Genetic interactions among floral homeotic genes of Arabidopsis. Development 112:1-20.

Brukhin, V., Hernould, M., Gonzalez, N., Chevalier, C., and Mouras, A. 2003. Flower development schedule in tomato, Lycopersicon esculentum cv. Sweet Cherry. Sex. Plant Reprod. 15:311-320.

Christensen, N. M., Nicolaisen, M., Hansen, M., and Schulz, A. 2004. Distribution of phytoplasma in infected plants as revealed by real-time PCR and bioimaging. Mol. Plant-Microbe Interact. 17:1175-1184.

Coen, E. S., and Meyerowitz E. M. 1991. The war of the whorls: Genetic interactions controlling flower development. Nature 353:31-37.

Cordova, I., Jones, P., Harrison, N. A., and Oropeza C. 2003. In situ PCR detection of phytoplasma DNA in embryos from coconut palms with lethal yellowing disease. Mol. Plant Pathol. 4:99-108.

Cousin, M. T., and Abadie, M. 1982 Action des mycoplasmes sur l'anthère. Etude en microscopies photonique et électronique. Rev. Cytol. Biol. Végét.-Bot. 5:41-57.

Doerner, P. 2001. Plant meristems: A ménage à trois to end it all. Curr. Biol. 11:785-787.

Farbos, I., Mouras, A., Bereterbide, A., and Glimelius, K. 2001. Defective cell proliferation in the floral meristem of alloplasmic plants of Nicotiana tabacum leads to abnormal floral organ development and male sterility. Plant J. 26:131-142.

Frohlich, M. W., and Parker, D. S. 2000. The mostly male theory of flower evolution: From genes to fossils. Syst. Bot. 25:155-170.

Gabe, M. ed.1968. Pages 67-162 in: Techniques Histologiques. Masson \& Cie, Paris.

Gocal, G. F., King, R. W., Blundell, C. A., Schwartz, O. M., Andersen, C. H., and Weigel, D. 2001. Evolution of floral meristem identity genes. Analysis of Lolium temulentum genes related to APETALA1 and LEAFY of Arabidopsis. Plant Physiol. 125:1788-1801.

Germain, V., Raymond, P., and Ricard, B. 1997. Differential expression of two tomato lactate dehydrogenase genes in response to oxygen deficit. Plant Mol. Biol. 35:711-721.

Hill, A. V. 1943. Insect transmission and host plants of virescence (big bud of tomato). J. Counc. Sci. industry. Res. Aust. 16:85-90.

Jarausch, W., Jarausch-Wehrheim, B., Danet, J. L., Broquaire, J. M. Dosba, F., Saillard, C., and Garnier, M. 2001. Detection and identification of European stone fruit yellows and other phytoplasmas in wild plants in the surroundings of apricot chlorotic leaf roll-affected orchards in southern France. Eur. J. Plant Pathol. 107:209-217.

Jacobsen, S. E., Sakai, H., Finnegan, E. J., Cao, X., and Meyerowitz, E. M. 2000. Ectopic hypermethylation of flower-specific genes in Arabidopsis. Curr. Biol. 10:179-186.

Kishimoto, N., Sakai, H., Jackson, J., Jacobsen, S. E., Meyerowitz, E. M., Dennis, E. S., and Finnegan, E. J. 2001. Site specificity of the Arabidopsis methyltransferase demonstrated through hypermethylation of the superman locus. Plant Mol. Biol. 46:171-183.

Kostoff, D. 1933. Virus diseases causing sterility. Phytopathology 5:593-602.

Krizek, A., and Meyerowitz, E. M. 1996. The Arabidopsis homeotic genes APETALA3 and PISTILLATA are sufficient to provide the class $\mathrm{B}$ organ identity function. Development 122:11-22.

Kuske, C. R., and Kirkpatrick B. C. 1992. Phylogenetic relationships between the western aster yellows mycoplasma-like organisms and other prokaryotes established by $16 \mathrm{~S}$ rRNA gene sequence. Int. J. Sys. Bacteriol. 42:75-80.

Lee, I. M., and Davis, R. E. 1992. Mycoplasmas which infect plants and insects. Pages 379-390 in: Mycoplasmas: Molecular Biology and Pathogenesis. J. Maniloff, R. N. McElhansey, L. R. Finch, and J. B. Baseman, eds. American Society of Microbiology, Washington, D.C

Lee, I. M., Gundersen-Rindal, D. E., and Bertaccini, A. 1998. Phytoplasma: Ecology and genomic diversity. Phytopathology 88:1359-1366.

Lee, I. M., Davies, R. E., and Gundersen-Rindal, D. E. 2000. Phytoplasma: Phytopathogenic mollicutes. Annu. Rev. Microbiol. 54:221-255.

Lenhard, M., Bohnert, A., Jürgens, G., and Laux, T. 2001. Termination of stem cell maintenance in Arabidopsis floral meristems by interactions between WUSCHEL and AGAMOUS. Cell 105:805-814
Lepka, P., Stitt, M., Moll, E., and Seemüller, E. 1999. Effect of phytoplasmal infection on concentration and translocation of carbohydrates and amino acids in periwinkle and tobacco. Physiol. Mol. Plant Pathol. 55:59-68

Lita, P.Y ., Miller, A. K., and Clark, S. E. 2003. POLTERGEIST encodes a protein phosphatase $2 \mathrm{C}$ that regulates CLAVATA pathways controlling stem cell identity at Arabidopsis shoot and flower meristems. Curr. Biol. 13:179-188.

Lohmann, J. U., Hong, R. L., Hobe, M., Busch, M. A., Parcy, F., Simon, R., and Weigel, D. 2001. A molecular link between stem cell regulation and floral patterning in Arabidopsis. Cell 105:793-803.

Lohmann, J. U., and Weigel, D. 2002. Building beauty: The genetic control of floral patterning. Develop. Cell 2:135-142.

Marchoux, G., and Messiaen, C. M. 1967. Note sur le virus du stolbur de la tomate chez le piment. Etudes de virologie, Ann. Epiphyties 18:179182.

Marchoux, G., Giannotti, J., and Laterrot, H. 1969. Le stolbur P, une nouvelle maladie de type jaunisse chez la tomate. Symptômes et examen cytologique des tissus au microscope électronique. Ann. Phytopathol. 4:633-640.

Maust, B. E., Espedas, F., Talavera, C., Aguilar, M., Santamaria, J. M., and Oropeza, C. 2003. Changes in carbohydrate metabolism in coconut palms infected with the lethal yellowing phytoplasma. Phytopathology 93:976-981.

Meissner, R., Jacobson, Y., Melamed, S., Levyatuv, S., Shaley, G., Ashri, A., Elkind, Y., and Levy, A. 1997. A new model system for tomato genetics. Plant J. 12:1465-1472.

Messiaen, C. M., and Marrou J. 1967. Comparaison de la virulence sur diverses solanacées de trois souches de stolbur et d'un virus attaquant la tomate. Etudes de virologie. Ann. Epiphyties 18:173-178.

Ohto, M., Onai, K., Furukawa, Y., Aoki, E., Araki, T., and Nakamura, K. 2001. Effects of sugar on vegetative development and floral transition in Arabidopsis. Plant Physiol. 127:252-261.

Parcy, F., Nilsson, O., Busch, M. A., Lee, I., Weigel, D. 1998. A genetic framework for floral patterning. Nature 395:561-566.

Pracros, P., Desqué, D., Baron, J., Bonnet, P., Foissac, X. and Garnier, M. 2001. Phylogenic characterisation of phytoplasma isolates maintained in the sieve tube-restricted bacterial pathogens collection in Bordeaux. 14th International Congress of the International Organization for Mycoplasmology, Vienna, Austria.

Reeves, P. H., and Coupland, G. 2001. Analysis of flowering time control in Arabidopsis by comparison of double and triple mutants. Plant Physiol. 126:1085-1091.

Seemüller, E., Marcone, C., Lauer, U., Ragozzino, A., and Göschl, M. 1998. Current status of molecular classification of the phytoplasmas. J. Plant Pathol. 80:3-26.

Seemüller, E., Garnier, M., and Schneider, B. 2002. Mycoplasmas of plants and insects. Pages 91-115 in: Molecular Biology and Pathogenicity of Mycoplasmas. S. Razin and R. Herrmann, eds. Kluwer Academic/ Plenum Publishers, New York.

Valenta, V., Musil, M., and Misiga, S. 1961. Investigations on European yellows type viruses. I. The stolbur virus. Phytopathology. 42:1-39.

Weigel, D., and Meyerowitz, E. M. 1993. Activation of floral homeotic genes in Arabidopsis. Science 261:1723-1726.

Weigel, D., and Meyerowitz, E. M. 1994. The ABCs of floral homeotic genes. Cell 78:203-209.

Weigel, D., and Nilsson, O. 1995. A developmental switch sufficient for flower initiation in diverse plants. Nature 377:495-500.

Weisburg, W. G., Tully, J. G., Rose, D. L., Petzel, J. P., Oyaizu, H., Yang, D., Mandelco, L., Sechrest, J., Lawrence, T. G., Van Etten, J., Maniloff, J., and Woese, C. R. 1989. A phylogenetic analysis of the mycoplasmas: Basis for their classification. J. Bacteriol. 171:64556467

Wu, X., Dabi, T., and Weigel, D. 2005. Requirement of homeobox gene STIMPY/WOX9 for Arabidopsis meristem growth and maintenance. Curr. Biol. 15:436-440

Yanofsky, M. F. 1995. Floral meristems to floral organs: Genes controlling early events in Arabidopsis flower development. Annu. Rev. Plant Physiol. Plant Mol. Biol. 46:167-188. 